\title{
Human Resource Management Practices in the Era of Khulafä' al-Räshidīn (11-40 AH / 632-661 AD)
}

\author{
Ilhaamie Abdul Ghani Azmi \\ University of Malaya, amieazmi@um.edu.my \\ Norhayati Hamzah \\ University of Malaya, yati611@um.edu.my
}

\begin{abstract}
Quality human capital is significant to every organization due to the fact that it is not only an asset to employer but indeed determining the increase of organizational performance. Human resource management practices in Islamic Civilization aim at selecting and producing quality human capital. These practices have been applied in Islamic history since the early period of Islam especially in the era of Khulafă' al-Rāshidīn that comprises the caliphate of Abū Bakr al-Ṣiddīq, 'Umar al-Khattāb, 'Uthmẓn b. 'Affān and 'Alī b. Abi Ṭālib. Hence, this article will elaborate the implementation of human resource management practices i.e. selection and recruitment of workers, training and development as well as salary during the above mentioned period. Human resource management practices that were implemented in the era of Khulafä' alRāshidin is certainly a continuous policy of the Prophet Muhammad (p.b.u.h.).
\end{abstract}

Keywords: Khulafā'al-Rāshidīn, selection and recruitment of workers, training and development, salary

\section{Introduction}

Human Resource Management is a term used to describe a wide range of activities involved in attracting, developing, motivating and retaining the best and most capable people to perform within an organization. ${ }^{1}$ It also refers to activities comprising human resource policies, practices and processes. ${ }^{2}$ Paul and Ananthraman stated that there are four main human resource management functions which are recruitment and selection, training and

1 I.S.C. Hau and P.F. Ping, "Change and Development in Pluralistic Settings: An Exploration of Human Resource Practices in Chinese Township and Village Enterprises," International Journal of Human Resource Management 11, no.4 (2000): 822-836.

2 N. Khatri, "Managing Human Resource for Competitive Advantage: A Study of Companies in Singapore," International Journal of Human Resource Management 11, no.2 (2000): 336-365. 
development, performance appraisal as well as compensation and benefits. ${ }^{3}$ Human Resource Management also indicates employing people, developing their resources, utilizing, maintaining and compensating their services in tune with the job and organizational requirement. It refers to a model of personnel management that focuses on individual rather than taking a collective approach. It is characterized by an emphasis on strategic integration, employee commitment, workforce flexibility, and quality of goods and services. Generally, these definitions explain an almost similar point that is human resource management concentrates on employees' selection and recruitment, training and development, salary and benefit which are the main discussions of this article.

Human Resource Management is essential since it determines the progress and development of an organization and simultaneously, a country and a civilization. This is parallel to the main purpose of human resource management from Islamic perspective that is to select and produce quality human resource. Selection of quality human will result in quality work that leads to the development of an organization and a civilization. This is proven in the golden days of Islam starting from the caliphate of al-Rāshidīn until the Umayyad's caliphate in Andalus (Spain). From Islamic perspective, Islam gives great recognition to humans as caliphs on earth and concurrently as servants of Allah. In other words, humans play an essential role in building and developing their civilizations and ensuring the world is in prosperity. In order to perform those responsibilities, humans are given knowledge as been narrated in the Qur'ān on the creation of Prophet Adam as the first human and caliph on earth and the knowledge bestowed to him by Allah:

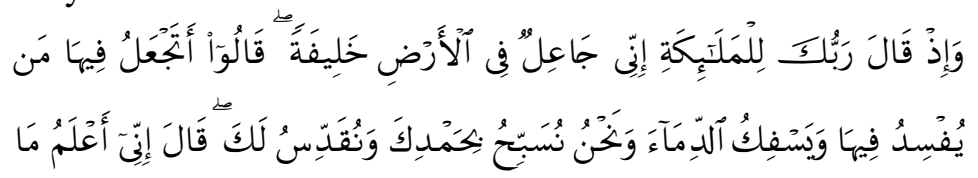

3 A.K. Paul and R.N. Anantharaman, "Impact of People Management Practices on Organizational Performance: An Analysis of a Casual Model," International Journal of Human Resource Management 14, no. 7 (2003): 1246-1266; K. Singh, "The Effect of Human Resource Practices on Firm Performance in India," Human Resource Development International 6, no.1 (2003): 101-116. 


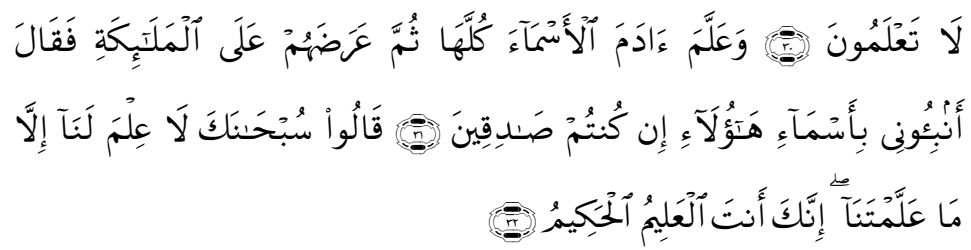

al-Baqarah 2:30-32

Translate: "And (remember) when your Lord said to the angels: "Verily, I am going to place (mankind) generations after generations on earth." They said: "Will You place therein those who will make mischief therein and shed blood, while we glorify You with praises and thanks and sanctify You." He (Allah) said: "I know that which you do not know." And He taught Adam all the names (of everything), then $\mathrm{He}$ showed them to the angels and said, "Tell me the names of these if you are truthful."4

In view of the fact that humans are the best creation of Allah on earth as indirectly mentioned in the above verses and that they being assigned the duty as caliphs, humans are anticipated to possess quality behaviour as prescribed by Islam such as trust, patience, honesty, responsibility, diligence, etc. These qualities are the main teachings of Islam as being revealed in Qur'ān. In fact, the Prophet Muhammad (p.b.u.h.) is known of his excellent qualities as been described in Sūra al-Qalam, "And Verily, you $(O$ Muhammad) are on exalted (standard of) character." And he had hitherto remained the model of Qur'anic behaviour for Muslims. Below are amongst the verses in Qur'ān pertaining the qualities:

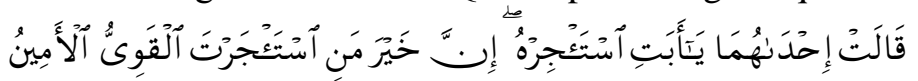

al-Qașaș 28:26

Translate: "...Verily, the best men for you to hire is the strong, the trustworthy."

4 See Muhammad Taq̄i al-Dīn al-Hilalī and Muḥammad Muḥs̄̄n Khān, Noble Qur'an English Translation of the Meanings and Commentary (Madinah alMunawwarah: King Fadh Complex For The Printing of the Holy Qur'an, 1997), 7- 8.

5 Al-Qalam 68:4. 


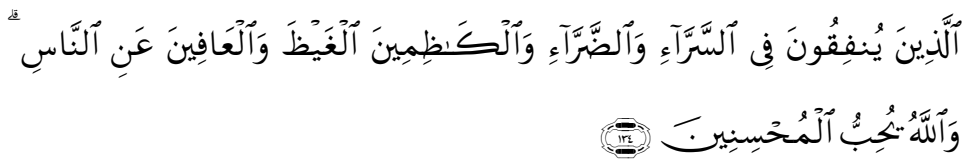

Āli-'Imrān 3:134

Translate: "Those who spend (in Allah's cause) in prosperity and in adversity, who repress anger, and who pardon men; verily, Allah loves Al-Muhsinun (the good-doers)."

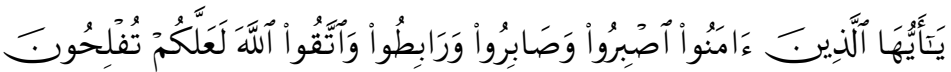

Āli-'Imrān 3:200

Translate: "O you who believe! Endure and be more patient (than your enemy), and guard your territory by stationing army units permanently at the places from where the enemy can attack you, and fear Allah, so that you may be successful."

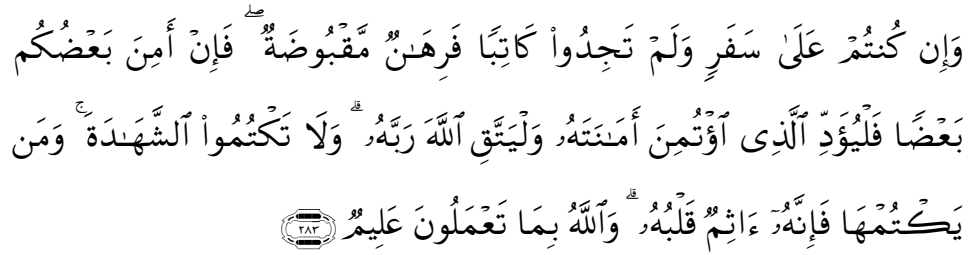

al-Baqarah 2:283

Translate: "If ye are on a journey, and cannot find a scribe, a pledge with possession (may serve the purpose). And if one of you deposit a thing on trust with another, Let the trustee (Faithfully) discharge His trust, and let him fear his Lord. Conceal not evidence; for whoever conceals it, his heart is tainted with sin. And Allah Knoweth all that ye do."

In term of human resource management, the above mentioned qualities such as strong, trustworthy, ${ }^{6}$ patient and forgivable are among the qualities of employees that should be employed and trained in order to achieve the goal of an organization. Thus, the present practice of human resource management should take these qualities into consideration in selecting and recruiting employees. Selection and appointment of quality workers were constantly

6 Hezam Mater al-Mutairi, "An Islamic Perspective on Public Service with Reference to the Hajj Research Center (HRC)," (Ph.D Thesis, State University of New York, 1987), 74-75. 
practised by caliphs in Islamic history. ${ }^{7}$ In order to ensure that candidates have all the mentioned elements or qualities of the human resource management from Islamic perspective, interviews had been carried out during the Golden Age of Islam (Khulafä' alRāshidīn). Generally, officers were selected from among the Sahābah (the companions of the Prophet Muhammad (p.b.u.h.) as they possessed the above qualities such as piety, responsibility, honesty, patience, obedience, commitment, etc. Indeed, the Sahābah contributed to the building and development of Islamic civilization. Amongst were, 'Abd al-Raḥmān b. 'Awf, Abū 'Ubayda b. Al-Jarrāh, Zayd b. Thābit, etc. 'A 'Abd al-Raḥmān b. 'Awf and Abū 'Ubayda b. Al-Jarrāh for examples were known of his piety and responsibility as they were prominent companions of the Prophet and among the early converts to Islam. ${ }^{9}$ 'Abd alRahimān b. 'Awf was assigned the responsibility as one of the panels in the council of Shürā (the Council of Advisors) to select a caliph after 'Umar and Abū 'Ubayda b. al-Jarrāh was one of the companions of the Prophet who was well known of his strength and obedience. He proved to be a successful commander in chief of the Muslim army in Syria during 'Umar.

\section{Selection and Recruitment of Employees in the Era of Khulafä' al-Rāshidīn}

Khulafä' al-Rāshidīn witnessed the reign of four caliphs, Abū Bakr al-Șiddīq (11-13/632-634), 'Umar al-Khatțāa (13-23/634644), 'Uthmān b. 'Affān (23-35/644-656) and 'Alī b. Abī Țālib (35-40/656-661). ${ }^{10}$ Regarding the selection of employee, several criteria will be firstly decided in a meeting. In Islamic Civilization, two criteria have been implemented in selecting employee:

\footnotetext{
Al-Mutairi, "An Islamic Perspective on Public Service with Reference to the Hajj Research Center (HRC)," 74-75.

8 Muḥammad b. Aḥmad b. 'Uthmān al-Dhahabī, Tārīkh al-Islām wa-Tabaqāt al-Mashāhir wa al-'Alām (Cairo: Maktabah al-Qudsī, 1927), 87 and 297; Majid Ali Khan, The Pious Caliphate (Kuala Lumpur: Islamic Book Trusts, 1998), 35; Hugh Kennedy, The Prophet and the Age of the Caliphates (London and New York: Longman, 1986), 51.

9 Hugh Kennedy, The Prophet and the Age of the Caliphates, 75.

10 Abū Bakr al-Ṣiddīq, 'Umar al-Khaț̣āb, 'Uthmān b. 'Affān and 'Alī b. Abī Țālib are amongst the Șahābah (the companions of the Prophet Muhammad (p.b.u.h.) who had supported the Prophet and contributed to the survival and development of Islam during the early days of Islam).
} 
personal traits such as responsible and honest, and strength, ${ }^{11}$ for examples qualification, ability, excellent health and working record. In the time of Abū Bakr, selection of employees i.e. officers were given to people of high merit such as 'Amr al-'Aș and Abū Mūsā al-'Ash'arī who were the companions of the Prophet. ${ }^{12}$ Their appointments were parallel to the mentioned above criteria from the Islamic perspective that are strength and personal traits as well as piety. 'Amr al-'Ạs ( A.D. 575-664) was indeed among the major narrators of Hadith as well as one of the commanders of Muslim armies to Syria while Abū Mūsā al'Ash'ari since the period of the Prophet had been involving in the early Muslim conquest. Upon the selection of 'Amr al-'Ạ Abū Bakr advised him as below:

"Fear Allah openly and secretly. Whosoever fears Allah, He provides him sustenance from such source about which he never thought. Whosoever fears Allah, Allah forgives his sins and gives him double reward. No doubt to have good will for the people is great piety. You are on such a way that may go beyond the prescribed limits easily. Stick to the rules prescribed by the religion and that would save you from all evils." 13

Apart from the above, Abū Bakr selected and appointed Usāma b. Zayd, ${ }^{14}$ an eighteen year old young man to lead a military expedition to Syria despite the doubts among the Anșār on the ability of Usāma. ${ }^{15}$ Appointment of Khālid b. al-Walīi, a new

11 Al-Mutairi, "An Islamic Perspective on Public Service with Reference to the Hajj Research Center (HRC)," 73-75.

12 Refer to Husayn Ahmad Amin, Seratus Tokoh dalam Sejarah Islam (Bandung: Penerbit PT Remaja Rosdakarya, 1999), 19; Hasanuddin Ahmed, A Concise History of Islam: Essays on the Religio-Political History of Islam (New Delhi: Goodwork Books, 2008), 80; Majid Ali Khan, The Pious Caliphate, 44 and 47.

${ }^{13}$ Hugh Kennedy, The Prophet and the Age of the Caliphates, 45.

14 Usāmā b. Zayd is the son of Zayd b. Hāritha, an adopted son of the Prophet Muhammad (p.b.u.h.). Before the death of the Prophet, he appointed Usāmā as the commander of the expedition to Syria and his policy was continued by Abū Bakr despite the fact that Usāma was inexperience and young. See Wilferd Madelung, The Succession to Muhammad: A Study of the Early Caliphate (New York: Cambridge University Press, 1997), 46.

15 'Izz al-Dīn Ibn al-Athīr, Al-Kāmil fì Tārīkh (vol. 3-Beirut: Dār al-Ṣādir, 1979), 334-335; 'Abd al-Wahāb al-Najjār, Al-Khulafā' al-Rāshidūn (Beirut: Dār alKutub al-'Ilmiyyah, 1990), 39-41; Sir William Muir, The Caliphate Its Rise, 
convert as commander-in-chief of the four armies sent to Syria also proves a good example of meritocracy and piety in selection and recruitment. ${ }^{16}$ Khālid b. al-Walīd is known as Sayf Allāh (the Sword of Allah) and one of the well-known military commanders in Islamic history. ${ }^{17}$ Despite his late conversion to Islam i.e. after the Treaty of Hudaybiyya in $6 / 628$, Khālid proved to be a good Muslim and succeeded in gaining the Prophet's confidence. He was then appointed by the Prophet to lead the Muslim armies against the Byzantium and he remained in service as the leader of the armies till 'Umar al-Khațāâ. ${ }^{18}$ Both expeditions were successful and these proved the accuracy of Abu Bakr's policy in appointing employees. As mentioned, Abū Bakr's selection and appointment of officers were generally based on experiences, capabilities and the utmost, pieties. Besides the above officers, several others were appointed to different posts in the government. For instance, 'Umar al-Khațtāb, Alī b. Abī Țālib, 'Abd al-Raḥmān b. 'Awf, Zayd b. Thābit and Mu'adh b. Jabal as Qadis (Judges), Abū Mūsā al-Ash arī, Jarīr b. 'Abd Allāh, 'Utāb b. Asad, 'Uthmān b. Abī al-'Ạṣ and Ziyād b. Labīd as governors. ${ }^{19}$ Their appointments were consistent with the principle of human resource management from Islamic perspective as they were among the

Decline, and Fall (London: Darf Publisher, 1984), 9; Hugh Kennedy The Prophet and the Age of the Caliphates, 53.

16 Ibn al-Athīr, Al-Kāmil fì Tārīkh, 407; Muhammad al-Sayyīd al-Wakīl, Jawlah Tārikhiyah fì 'Aṣr al-Khulafā' al-Rāshidīn (Jeddah: Dār al-Mujtama', 1997), 60; 'Alī Muḥammad Muhammad al-Ṣallābī, Al-Khulafā' al-Awwal Abū Bakr al-Siddīq (Beirut: Dār al-Ma'rifah, 2005), 308-311; 'Abd al-Wahāb al-Najjār, Al-Khulafa' Al-Rashidun, 77-78; Mokhtar Abdullah, Noreha Hussain, Nik Mustapha Nik Hassan and Mazilan Musa, Essays on Islamic Management and Organizational Performance Measurements (Kuala Lumpur: IKIM, 2003), 54; Talib Samat, Abu Bakar As-Siddiq Khalifah Al-Rasyidin Pertama (Shah Alam: Karisma Publications, 2004), 179.

17 Al-Dhahab̄i, Tārīkh al-Islām wa-Ṭabaqāt al-Mashāhir wa al-‘Alām, 130-131; 'Abd Wahāb Al-Najjār, Al-Khulafā' Al-Rāshidūn, 93.

18 Abī Ja'far Muhammad b. Jarīr al-Ṭabarī, Tārīkh al-Rusūl wa al-Mulūk (Mesir: Dār al-Ma‘ārif, 1962), 3:599-560; Ibn al-Athīr, Al-Kāmil fī Tārīkh, 410-411; Husayn Ahmad Amin, Seratus Tokoh dalam Sejarah Islam, 10; Muḥammad al-Sayyīd al-Wakīl, Jawlah Tārikhiyah fì 'Așr al-Khulafā' al-Rāshidīn, 62-64.

19 Ibn al-Athīr, Al-Kāmil fì Tārīkh, 407 and 421; al-Șallābī, Al-Khulafā' alAwwal Abū Bakr al-Ṣiddīq, 149; 'Abd Wahāb Al-Najjār, Al-Khulafā' alRāshidūn, 96; Majid Ali Khan, The Pious Caliphate, 46. 
people of high merits, pieties and experienced who rendered great services to Islam.

The rule of Abū Bakr came to an end with his death in 13/634 and was succeeded by 'Umar al-Khattāâ. ${ }^{20}$ The golden age of Islam occurred during the reign of 'Umar al-Khatțāb, who pursued the Islamic policy in his administration. ${ }^{21}$ Umar was the pioneer of modern civilization who formed a state based on the Islamic democratic system and thus, became the greatest democratic administrator. ${ }^{22}$ In term of selecting and appointing the most qualified employee, 'Umar chose piety as one of the criteria similar to that of $\mathrm{Abu}$ Bakr. ${ }^{23}$ In addition, he also gave priority to those who were efficient and capable in administration as well as possessing noble behaviour. This is clear in his statement, "Anyone who chooses for Muslims a person who is less qualified than other qualified people, thus he has betrayed Allah, His Prophets and the Muslims." ${ }^{24}$ Similarly, Abbas J. Ali quoted from Asaf by saying, "When a person is in charge of Muslim affairs and appointed for reasons of favoritism or kinship relationship (nepotism), then he cheats God, the Prophet, and the community.",25

In order to get the most qualified person, selection and appointment of employees under 'Umar's chalipate were based on certain procedures. The first procedure is distribution of duties and limitation of power (job analysis) ${ }^{26}$ In Islam, a post that is created

${ }^{20}$ Muḥammad b. Sa'ad Khāṭib al-Wāqidī, Kitāo al-Ṭabaqāt al-Kabīr (Leiden: Brill, 1810), 202; Al-Najjār, Al-Khulafā' al-Rāshidūn, 105-106.

21 Majid Ali Khan The Pious Caliphate, 80; Ira M. Lapidus, A History of Islamic Societies (USA: Cambridge University Press, 1988), 55.

22 Majid Ali Khan, The Pious Caliphate, 87 and 111.

${ }^{23}$ Mustafa Daud, Pengurusan Islam (Selangor: Utusan Publications and Distributors Sdn. Bhd., 1997), 149; Al-Mutairi, "An Islamic Perspective on Public Service with Reference to the Hajj Research Center (HRC)," 63.

24 Syed Omar Syed Agil, Sejarah Kepimpinan dalam Pentadbiran Islam dalam Pengurusan dan Pentadbiran (Kuala Lumpur: IKIM, 1998), 244-259; Hakim Mohammad Said, Hubungan Majikan Pekerja Menurut Islam, terj. Yusof Ismail (Kuala Lumpur: A.S. Noordeen, 1989), 166; Al-Mutairi, "An Islamic Perspective on Public Service with Reference to the Hajj Research Center (HRC)," 81.

25 Abbas J. Ali, "Islamic Challenges to HR in Modern Organizations," Personnel Review 39, no. 6 (2010): 692 - 71.

26 Al-Mutairi, "An Islamic Perspective on Public Service with Reference to the Hajj Research Center (HRC)," 76-77. 
needs to be firstly identified its function and jurisdiction before an appointment of a qualified employee is completed. Hence, caliph 'Umar identified the most qualified employee to hold a post by identifying the employee's administrative power limit where he said as below:

"Remember, I have not appointed you as commanders and tyrants over the people. I have sent you as leaders instead, so that the people may follow your example. Give the Muslims their rights and do not beat them lest they become abused. Do not praise them unduly, lest they fall into the error of conceit. Do not keep your doors shut in their faces, lest the more powerful of them eat up the weaker ones. And do not behave as if you were superior to them, for that is tyranny over them. ${ }^{27}$

The second procedure is interview which is the basis of selecting employees in Islam. ${ }^{28}$ 'For instance, once $\mathrm{Mu}^{\mathrm{e}} \mathrm{a} \mathrm{dh}$ b. Jabal had been interviewed before being appointed as a $Q \bar{a} d \bar{\imath}$ (Muslim Judge) to Yemen. ${ }^{29}$ The Prophet Muhammad (p.b.u.h.) asked Mu'ādh, "According to what will you judge?" He replied, "According to the Book of Allah." The prophet then asked, "If you did not find anything in it?" He answered, "According to the Sunna of the Prophet." "And if you did not find anything in it?" He said, "I will exert myself to form my own judgement." Resembling the prophet, 'Umar was very careful in appointing employees especially governors and $Q \bar{a} d \bar{l} s$ at different places in Islamic provinces. Qualification, efficiency and ability of a candidate were the main considerations besides noble behaviour, piety, trustworthy, gentleness and respectful. ${ }^{31}$ Therefore, in order

27 Al-Najjar, Al-Khulafā' al-Rāshidūn, 212; Junaidah Hashim, Human Resource Management: Islamic Approach (PJ: Prentice Hall, 2007), 86; Al-Mutairi, "An Islamic Perspective on Public Service with Reference to the Hajj Research Center (HRC)", 67; "Umar," website Wikipedia, retrieved on 20 July 2010, http://en.wikipedia.org/wiki/Umar.

28 Al-Mutairi, "An Islamic Perspective on Public Service with Reference to the Hajj Research Center (HRC)," 76 - 79.

29 Al-Mutairi, "An Islamic Perspective on Public Service with Reference to the Hajj Research Center (HRC)," 76 - 79.

30 C.G. Weeramantry, Islamic Jurisprudence an International Perspective (Kuala Lumpur: The Other Press, 2001), 31.

31 Ahmad Ibrahim Abu Sin, Pengurusan dalam Islam (Kuala Lumpur: Dewan Bahasa dan Pustaka, 1997), 149-150. 
to meet the mentioned elements required for a job, interview was carried out under 'Umar's chalipate and the successful candidate would be appointed after consultations with the Shīrā. In the era of 'Umar, several $Q \bar{a} d \bar{l} \bar{s}$ were appointed amongst, Zayd b. Thābit, 'Abd Allāh b. Mas'ūd, Abū al-Dardā', Qays b. Abī al-'Āṣ alSahamī' ${ }^{-32}$ and 'Abd al-Rahmān b. Rabī. The carefulness of 'Umar in selecting employees in accordance to the criteria of Islamic perspective as mentioned above was evidenced through the appointment of the mentioned $Q \bar{a} d \bar{l} \bar{s}$ as they were among the most pious, trustworthy and respectful Muslims of his time. ${ }^{33}$ Upon their appointment, 'Umar advised the $Q \bar{a} d \bar{\imath} \bar{s}$ to decide cases firstly, according to the Qur' an and secondly, according to the Sunnah. If they do not find any solution in them, they should refer to the Ijma' and if they still do not find any solution, then only they can make their own verdict (Ijtihād). ${ }^{34}$

The third procedure is that selection of employee is done by a team work. ${ }^{35}$ Selection is done after the process of interviewing. In the time of 'Umar, the constitution of Islamic state was based on the Islamic democratic system. All matters including selection and appointment of employees/officers were decided after consulting the Shürā. ${ }^{36}$ The Shūrā emphasized on selecting the most honest and capable employees for the posts of governor and military commander. In this discussion, 'Umar sought opinions from the Sahābah, who were mainly the members of Shürä. ${ }^{37}$ Once he asked his companions what would they think if he appointed one whom he believed to be the best man among them and ordered him to do justice, would 'Umar assume his responsibility? The

\footnotetext{
Al-Najjār, Al-Khulafā' al-Rāshidūn, 206.

33 Majid Ali Khan, The Pious Caliphate, 87-88; Naceur Jabnoun, Islam and Management (Kuala Lumpur: Institut Kajian Dasar, 1994), 95.

${ }^{34}$ Majid Ali Khan, The Pious Caliphate, 95.

35 Ahmad Ibrahim Abu Sin, Pengurusan dalam Islam, 151.

36 Al-Najjār, Al-Khulafā' al-Rāshidūn, 211 and 235; Ahmad Ibrahim Abu Sin, Pengurusan dalam Islam, 190; Majid Ali Khan, The Pious Caliphate, 93; AlMutairi, "An Islamic Perspective on Public Service with Reference to the Hajj Research Center (HRC)," 80.

37 Mustafa Daud, Pengurusan Islam, 149.
} 
companions replied saying yes. 'Umar retorted, no, not unless he saw whether the appointee did the task he was ordered to do' ${ }^{38}$

Once a governor or officer was appointed, 'Umar will hand over an agreement consists of the employee's working status, post, authority and responsibility or in other words, the conduct of governors. ${ }^{39}$ The appointment will be signed and sealed by the caliph himself and being witnessed by amongst the Anșār (the inhabitants of Medina who supported Muhammad or Helpers of the Prophet) and Muhajirīn (the Prophet's followers in Makkah who participated in the Hijra). ${ }^{40}$ Before a governor departs to his assigned province, the masses will gather at the mosque to listen to the announcement of the appointment. The caliph will then declare the appointment and read the instructions to enable the people to know the responsibility and limitation of power of the newly appointed governor or officer which has been mentioned above. ${ }^{4}$

As mentioned, 'Umar was a vigilant caliph and thus, his governors would be highly scrutinized. ${ }^{42}$ Indeed, their performance would be assessed from time to time and if found the governor possessed properties exceeded his income, the property would be confiscated and defined as committing corruption. As testing for filling a job is a principle in Islam and was practised by the Prophet, ${ }^{43}$ Naceur Jabnoun in his book quoted from Al-Bureay stated that 'Umar used to test the performance of his governors by appointing them on ad-hoc basis for two to three months prior to their regular appointments. ${ }^{44}$ Meanwhile, some mentioned from six months to two years. ${ }^{45}$. 'Umar said to one of his officers, "This

38 Naceur Jabnoun, Islam and Management (Kuala Lumpur: Institut Kajian Dasar, 1994), 105-193; Al-Mutairi, "An Islamic Perspective on Public Service with Reference to the Hajj Research Center (HRC)," 83.

39 Al-Mutairi, "An Islamic Perspective on Public Service with Reference to the Hajj Research Center (HRC)," 77.

40 Al-Mutairi, "An Islamic Perspective on Public Service with Reference to the Hajj Research Center (HRC)," 77.

${ }^{41}$ Ahmad Ibrahim Abu Sin, Pengurusan dalam Islam, 149; Mustafa Daud, Pengurusan Islam, 149.

42 Al-Mutairi, "An Islamic Perspective on Public Service with Reference to the Hajj Research Center (HRC)," 83.

43 Al-Mutairi, "An Islamic Perspective on Public Service with Reference to the Hajj Research Center (HRC)," 79.

44 Naceur Jabnoun, Islam and Management, 105-193.

45 Ahmad Ibrahim Abu Sin, Pengurusan dalam Islam, 153. 
appointment is a trial for you. If you are able to work excellently, I will confirm your post. I will terminate your service otherwise." ${ }^{\$ 46}$ Abbas J. Ali quoted from Kurd Ali saying that 'Umar said to one of his officers, "I appointed you to test you. If you do well, I will promote you; but if you do not, then I will dismiss you." ${ }^{47}$ Once, 'Umar assigned Shurhabīl bin Hasana as the governor of Syria and later replaced him by Mu'āwiya b. Abī Sufyān. The former later enquired 'Umar of his action and whether he was angry with him. 'Umar replied that he liked him but he just needed a stronger man. This event shows that 'Umar was very concerned with the quality of his employees and would replace them with the better one if he found one. ${ }^{48}$ Similarly, the governor of Basrah, al-Mughīa b. Shu'bah was replaced by Abū Mūsā al-Ash ${ }^{\text {arī. }}{ }^{49}$ Al-Mughīra b. Shu'bah was deposed due to alleged adultery and this conduct is against Islam as well as the human resource management practise from Islamic perspective. Amongst the governors appointed in 'Umar's period were Nāfi' b. Abū Harīth (Medina), Abū Mūsā al'Ash'arī (Iraq) and 'Amr al-'Āṣ (Egypt). Their appointments were parrallel to'Umar's policy in selecting and recruiting employees which is based on Islamic policy where piety, responsibility, trustworthiness, honesty, capability, etc. became the main considerations. ${ }^{50}$ In order to ensure that there will be not be any misuse of power and the existence of bribery, officers appointed were compulsory to declare their properties. Consequently, 'Umar was able to protect the rights of the people. ${ }^{51}$

As a pious caliph, 'Umar's policy of selecting and appointing employees were carried out fairly and transparently. Once, 'Umar refused to appoint his child as recommended by the Sahăbah and his officials by saying, "Let only one from al-Khațāāb family to be

46 Ahmad Ibrahim Abu Sin, Pengurusan dalam Islam, 153.

47 Abbas J. Ali, "Islamic Challenges to HR in Modern Organizations," Personnel Review 39 Iss: 6 (2010): 69 - 71.

48 Naceur Jabnoun, Islam and Management, 105-193.

49 Ibn al-Athīr, Al-Kāmil fì Tārìkh, 31-32; Hugh Kennedy, The Prophet and the Age of the Caliphates, 67.

50 Al-Mutairi, "An Islamic Perspective on Public Service with Reference to the Hajj Research Center (HRC)," 81.

51 Junaidah Hashim, Human Resource Management: Islamic Approach, 92; AlMutairi, "An Islamic Perspective on Public Service with Reference to the Hajj Research Center (HRC)," 83 - 84. 
responsible infront of Allah on humanity under his leadership." 52 This indicates 'Umar's character as a humble, pious, fair and responsible caliph and consequently reflected in his administration and reign. In his administration, 'Umar was totally realiable on the Muhājirūn such as selecting and appointing Sa ${ }^{\circ} \mathrm{ad}$ b. Abī Waqāṣ, Zubayr b. al-'Awwām, Abū 'Ubayda and 'Amr al-'Ạs to the most important posts. ${ }^{53}$ Besides, 'Umar gave priority to the Sábiqa (Early merit in Islam or Precedence in conversion to Islam) to fulfil the highest posts in his administration. ${ }^{54}$

The death of 'Umar in 23/643 put an end to his glorious caliphate and 'Uthmān b. "Affān succeeded him. ${ }^{55}$ 'Uthmān was one of the pious companions and is said as the most modest of all companions. ${ }^{56}$ The appointment of 'Uthmān as caliph is narrated in detail by al-Balādhurī mentioning the process of Shīrā consisting of 'Alī, 'Uthmān, Țalḥah, Zubayr, 'Abd al-Raḥmān b. 'Awf and Sa'ad b. Abī Waqqās to appoint the successor of 'Umar. ${ }^{57}$ After being a caliph, 'Uthmān continued 'Umar's policy that is to maintain the Shüra as the basis of his administration. The main members of the Shürā during Uthmān were Alī, Zubayr and Talha. Concerning selecting and appointing of employees, Uthmān appointed officers of high calibre to govern Islamic provinces such as Mu'āwiya b. Ab̄̄ Sufyān (Syria), 'Abdullah b. 'Āmīr (Bașrah) and Abū Mūsā al-'Ash arī (Kūfa). For examples, Mu'āwiya b. Abī Sufyān and 'Abd Allāh b. Āmir were appointed due to the criteria of strength and ability. Mu'āwiya b. Abī Sufyān had involved in Muslim conquest since the Prophet's time and had

\footnotetext{
52 Nor Azzah Kamri, "Nilai dan Etika dalam Pengurusan Islam" (Dissertation, Academy of Islamic Studies, University of Malaya, 2002), 108-137.

53 Hugh Kennedy, The Prophet and the Age of the Caliphates, 57.

54 Wilferd Madelung, The Succession to Muhammad, 1997), 58; Abbas J. Ali, "Islamic Challenges to HR in Modern Organizations," Personnel Review 39, no. 6 (2010), 692 - 71.

55 Jalāl al-Dīn 'Abd al-Raḥmān al-Suyūṭī, Tārīkh al-Khulafā' (Kaherah: Maṭba'at al-Fajālah al-Jadīdah, 1969), 153; Al-Wāqidī, Kitāb al-Ṭabaqāt alKubrā, 42-43.

56 Majid Ali Khan, The Pious Caliphate, 150.

57 Aḥmad b. Yahyāā al-Balādhurī, Anșāb al-Ashrāf (Baghdad: Maktabah alMuthanna, 1936), 15-25; Muhammad al-Sayyīd al-Wakīl, Jawlah Tārikhiyah fì 'Așr al-Khulafā' al-Rāshidìn, 307- 311.
} 
been appointed as governor since caliph ' $\mathrm{Umar}^{58}$ while 'Abd Allāh b. Āmīr was as a successful military leader and governor of Basra.

As a pious caliph, Uthmān wrote to his offcers advising them of their duties' and in some conditions, 'Uthmān sent his representative to enquire his officers. He did not disregard the mistakes committed by his officers especially the governors. For example, Sa'ad b. Abī Waqqāṣ, the governor of Iraq was removed and replaced by al-Walīd b. 'Uqba who was later removed due to his misconduct. Al-Walīd b. 'Uqba was accused of drinking liquor and being punished according to Sharī $a h .^{60}$ It is known that drinking liquor is forbidden in Islam and any leader involved in it was acting against the teaching of Islam and therefore was not entitled to his post. This is due to the fact that public job is a responsibility and also a burden in Islam, thus; those who are incapable to bear the burden and perform the responsibility should be dismissed. ${ }^{61}$ Besides that, 'Uthmān used to welcome public's complaints against his officers on every occasion of pilgrimage (Hajj). This shows 'Uthmān's concern on the quality and conduct of his governors and officers. Besides the names above, amongst officers during Uthmān's time were Abū Mūsā al-'Ash'arī, 'Alqamah b. al-Hākīm, 'Abd Allāh b. Haḍrāmī, 'Abd al-Raḥmān b. Khālid b. Walīd, Sa'īd b. al- 'Āṣ and 'Abd Allāh b. Mas'ūd. ${ }^{62}$ The last part of 'Uthmān's caliphate was full of rebellions due to discontents from the provinces of Iraq and Egypt on Uthmān's domestic policy. ${ }^{63}$ These revolts resulted in the murder of 'Uthmān on $17^{\text {th }}$ Dhū all-Hijjah, 35/656.

58 Hugh Kennedy, The Prophet and the Age of the Caliphates, 62.

59 Al-Najjār, Al-Khulafā' al-Rāshidūn, 248-249.

60 Al-Suyūțī, Tārīīh al-Khulafā', 104-105; Al-Balādhurī, Anșāb al-Ashrāf, 2935. Refer to Wilferd Madelung, The Succession to Muhammad q Study of the Early Caliphate, 86; William Muir, The Caliphate Its Rise, Decline, and Fall, 215; Al-Mutairi, "An Islamic Perspective on Public Service with Reference to the Hajj Research Center (HRC)," 70-71.

61 Al-Mutairi, "An Islamic Perspective on Public Service with Reference to the Hajj Research Center (HRC)," 70-71. According to al-Mutairi, any act of removal might be a result of physical and mental defect or because of dishonesty in carrying out a given task.

62 Al-Balādhurī, Anșāo al-Ashrāf, 36-39.

63 Al-Balādhurī, Anșāab al-Ashrāf, 25-26,59-72; Al-Suyūțî, Tārīkh al-Khulafā', 156. Al-Balādhurī and al-Suyūṭī narrate that 'Uthmān's attitude of appointing 
The assassination of 'Uthmān led to the succession of 'Alī b. Abī Tâalib as the fourth and the last caliph of Khulafā' alRāshidīn. ${ }^{64}$ Compared to the previous caliphs, 'Alī inherited a chaotic government where the political unity of Islam came to an end. ${ }^{65}$ Civil wars took place among Muslims and accordingly, the Islamic state of Medina became insecure. Indeed, Medina was without government for three days. Hence, 'Alī was asked to hold the responsibility as the new caliph but he refused due to the instability of the government. ${ }^{66}$ But later, "Ali decided to assume the responsibility for the sake of the ummah. As a new caliph, 'Ali resumed the administrative pattern of 'Umar and improved the administration of 'Uthmān which was improper in some places. ${ }^{67}$

Following the practices of his predecessors, selection and appointment of employees under were decided through interview and after consultation with the Shürä. Similar to the previous caliphs, 'Alī' stressed on the significance of interview in selection and appointment as it enables direct observation and assessment on a candidate. After a decision was made, an offer letter would be sent to the candidate. It contained the objective of the appointment and vision of the employee. "Alī emphasized on qualified candidate especially in term of technical and and personality which were clearly stated in his letter to the newly appointed governor of Egypt, Malik b. al-Ashtar as below:

"These are the commandments of "Ali to Malik ibn al-Ashtar upon his nomination as ruler of Egypt, to collect its taxes, to seek the welfare of its people and the rehabilitation of its land. He orders him to fear God... You should always refer to precedents of fair judgments, virtuous tradition or examples from the life of the Prophet, peace be upon him or stipulation

his relatives to important posts in the government led to dissatisfaction among people of different provinces of the Islamic state.

64 Al-Wāqidī, Kitāb al-Ṭabaqāt al-Kabīr, 20; Ibn al-Athīr, al-Kāmil fì Tārīkh, 3:167-169; Muhammad al-Sayyīd al-Wakīl, Jawlah Tārīkhiyah fì 'Așr alKhulafā' al-Rāshidīn, 433-434. 'Alī b. Abī Țālib belonged to the Banu Hashim, the most reputable family of Quraysh, his father Abī Tâlib was the paternal uncle of the Prophet and 'Alì was the first youth to embrace Islam. 'Alī was also a great warrior and scholar at his time.

65 Al-Najjār, Al-Khulafā' al-Rāshidūn, 346-347.

${ }^{66}$ Ibn al-Athīr, Al-Kāmil fì Tārīkh, 3:190.

67 Majid Ali Khan, The Pious Caliphate, 209. 
in the Quran and follow our example in adhering to them. Have a good look into the situation of your adminsitration. And choose their best men for your service. Entrust your confidential correspondence to those who are known for their good manners and noble character, who would not betray you in public or in private and who would not through negligence, delay the submission of the messages you receive from your officials or fail to send prompt responses to them in honesty and thoroughness.. Verily we are to return to Him". ${ }^{6}$

Besides the above criterion, 'Alī also stressed on true believer and pious candidate where he stated, "Appoint experienced person to hold important post that is a believer and of good family. Such person was not easy to be tempted and always carry his task for other people's benefit." ${ }^{69}$ Nevertheless, it does not mean that nonMuslims could not be appointed as employees. In the era of 'Alī, non-Muslims had been selected to hold important posts. In fact, they felt contented working under Islamic rule because their welfares and rights were protected. ${ }^{70}$ Caliph 'Alī rejected favouritism in selecting officers where he stated, "Do not choose people to work a task purely based on intuition, your affection or your good heart. ${ }^{71}$ Indeed many people are indeed dishonest, arrogant and do not belong to good family were able to cheat even an intelligent leader." He also refused to select an officer based on personal relationship in which he said, "Do not nominate them (officers) on account of favouritism or egoism. These two attributes reflect injustice and treachery."

68 Syed Omar Syed Agil, Djasriza Jasin and Fatimah Pa'Swan, "Nine Islamic Management Practices and Habits in Islamic History: Lesson for Managers and Leaders", UNITAR E-Journal 3, No.2 (2007), 47; Junaidah Hashim, Human Resource Management, 88; Abbas J. Ali, "Islamic Challenges to HR in Modern Organizations," 692-71; Al-Mutairi, "An Islamic Perspective on Public Service with Reference to the Hajj Research Center (HRC)," 81.

69 Syed Omar Syed Agil, Djasriza Jasin and Fatimah Pa'Swan, "Nine Islamic Management Practices and Habits in Islamic History: Lesson for Managers and Leaders," 49.

70 Syed Omar Syed Agil, Sejarah Kepimpinan dalam Pentadbiran Islam dalam Pengurusan dan Pentadbiran, 244-259.

71 Abbas J. Ali, "Islamic Challenges to HR in Modern Organizations," 692-71.

72 Junaidah Hashim, "Islamic Revival in Human Resource Management Practices Among Selected Islamic Organisations in Malaysia," International 
Wakhi who was heading for Egypt not to appoint an amil because of friendship or personal interest but after being questioned, probed and tested. ${ }^{73}$ "Ali said, "Monitor the behaviour of your assistants and use them only after probation .... Your discreet monitoring of their work will ensure that they remain honest and considerate to their subject."

In addition, "Ali also gave useful advice to his governors upon their appointment. For instance, he said to Ka'ab b. Malik, "Check officers of each and every district of Iraq thoroughly so that they may not act wrongly." concerned of his employees behavior especially the governors. In other words, "Alī did not allow his governors to abandon their duties and to act immorally. ${ }^{76}$ Once, he dismissed Mundhar b. Jarud, the governor of Istakhr due to his attitude of spending most of his time hunting rather than concentrating on administration. On the other hand, "Ali wrote to one of his governors advising him not to lead a luxurious life by neglecting the welfare of orphans and widows. ${ }^{77}$ Another example is that of $\mathrm{Nu}^{\text {'man }} \mathrm{b}$. 'Ujlan, a revenue officer who failed to deposit the revenues he had collected from the public in time and went to other places. 'Ali also wrote to him asking him to repent before Allah and pay all the revenues accumulated. ${ }^{78}$ Alî's act of writing to his governors, sending commissions to check on the officers and dismissing immoral governor shows Alī's strictness in his administration, i.e. to select and produce quality employees in accordance to the teaching of Islam. Amongst governors and officers appointed during 'Alī's țịme were 'Abd Allāh b. 'Abbās, Abū al-Aswad al-Dailī, Abū Ayyūb al-Anșārī and Qusam b. 'Abbās. ${ }^{79}$

Journal of Islamic and Middle Eastern Finance and Management 2, no. 3 (2009): 251-267.

73 Hakim Mohammad Said, Hubungan Majikan Pekerja Menurut Islam, 180.

74 Junaidah Hashim, Human Resource Management: Islamic Approach, 251267; Abbas J. Ali, "Islamic Challenges to HR in Modern Organizations," 69271.

75 Majid Ali Khan, The Pious Caliphate, 209.

76 Majid Ali Khan, The Pious Caliphate, 209.

77 Majid Ali Khan, The Pious Caliphate, 209.

78 Majid Ali Khan, The Pious Caliphate, 211.

79 Ibn al-Athīr, Al-Kāmil fì Tārīkh, 3:398. 


\section{Training and Development of Employees in the Era of Khulafä' Al-Räshidīn}

Seeking knowledge is compulsory for all Muslims in Islam and its significance is shown in the first verse revealed by Allah in the Qur'an. Thus, training and development as the means of seeking knowledge should be carried out by human resource managers. Through training and development either on job or off job, knowledge and skill of employees will increase and so does their performance. This will lead to the growth of organizational performance. The practice of training and development had been implemented under the four Khulafā' al-Rāshidīn.

As the most pious companion of the Holy Prophet, Abū Bakr was very concerned for the moral training of the military personnel..$^{80}$ In a military expedition to Syria, Abū Bakr advised and ordered them to treat their subordinates well, not to kill women, children and eldery, not to destroy any inhabited place, not to cut any flowering tree, etc. ${ }^{81}$ The significance of the advice is that Islam forbids any kind of destructions while preaching Islam and therefore, the army must be trained according to the teaching of Islam. This advice was manifested by Khālid b. Walīd in the Battle of Chains (Sallasil) when he stated to the Persians, "We have brought the message of Allah, Islam for you. Our aim is not to fight. Accept Islam, the peaceful way, and you will be safe. If not, then clear our way to the people so that we may explain this beautiful way of life to them..." ${ }^{82}$ Apart from the above, Abū Bakr was a strict administrator where he used to conduct supervisions over his officers and warned them if they were found behaving in an improper manner. Once he wrote to Khālid b. Walid and warned him by saying, "You are enjoying yourself whereas the blood of Muslims is flowing nearby your tent." ${ }^{\text {83 }}$ Abū Bakr also

${ }^{80}$ Ibn al-Athīr, Al-Kāmil fì Tärīkh, 46.

81 Al-Najjār, Al-Khulafā' al-Rāshidūn, 46; Al-Șallāb̄i, Al-Khulafā' al-Awwal Abū Bakr al-Șiddīq, 223; Abū Bakr also orderd his armies to fear Allah, to honour the representatives of their enemies, to be truthful, do not be dishonest in any way and do not disturb saints and worshippers of other religion.

82 Al-Najjār, Al-Khulafā' al-Rāshidūn, 78.

83 Al-Najjār, Al-Khulafā' 'al-Rāshidūn, 45. 
wrote to his governors with regards to management and training guides on judicial matters. ${ }^{84}$

With regards to training and development of the second caliph, 'Umar al- Khațāa oftenly sought opportunity to meet his governors and all Muslims during the pilgrimage. This general assembly could be said as a conference, congress and training to governors and provincial officers to share their opinions and experiences in solving management problems arose in their administration. ${ }^{85}$ During this assembly, the people were free to present any complaint against their governors. Besides that, 'Umar also sent monitors to check the performance of his officers. ${ }^{86}$ Meanwhile, Islamic conquest occurred within ten years of 'Umar's reign and it became one of the greatest achievements of 'Umar. Iraq, Iran, Syria, Palestine, Egypt and part of Turkey came under the domination of Islam. ${ }^{87}$

Due to the expansion of Muslim territories, army is of great importance and thus, 'Umar established a regular army of an Islamic State. Development of armies began with the establishment of settlement for armies where cantonments were built in Medina, Kufa, Basrah, Fustat, Mosul, etc. ${ }^{88}$ In addition, a $d \bar{\imath} w \bar{a} n$ system (list of those entitled to state salaries) was developed to manage the distribution of salaries and pensions to the army personnels. ${ }^{89}$ Caliph 'Umar also emphasized on physical training of the armies to ensure their fitness physically and mentally. Therefore, it is obligatory for every soldier to be trained in

${ }^{84}$ Mohd Yusri Ngah, "Latihan dalam Pembangunan Kerjaya dari Perspektif Pengurusan Islam: Kajian di ILHAM, MARA," (Dissertation, Academy of Islamic Studies, University of Malaya, 2004), 53.

85 Mohd Yusri Ngah, "Latihan dalam Pembangunan Kerjaya dari Perspektif Pengurusan Islam: Kajian di ILHAM, MARA," 53.

86 Abbas J. Ali, "Islamic Challenges to HR in Modern Organizations," 692 - 71.

87 Al-Suyūțī, Tārīkh al-Khulafā', 131-132; Al-Dhahabī, Tārīkh al-Islām, 150; Al-Najjār, Al-Khulafā' al-Rāshidūn, 162-172; Muhammad al-Sayyīd al-Wakīl, Jawlah Tārikhiyah fì 'Așr al-Khulafā' al-Rāshidìn, 238; Hugh Kennedy, The Prophet and the Age of the Caliphates, 57.

88 Majid Ali Khan, The Pious Caliphate, 108.

89 Ibn al-Athīr, al-Kāmil fĩ Tārīkh, 3:59; Al-Najjār, Al-Khulafā' al-Rāshidūn, 226-227; al-Suyūțī, Tārīkh al-Khulafä', 143; Hugh Kennedy, The Prophet and the Age of the Caliphates, 5 and 398; Muhammad al-Sayyīd al-Wakīl, Jawlah Tārikhiyah fì 'Așr al-Khulafā' al-Rāshidīn, 91. 
shooting, swimming and riding. ${ }^{90}$ The above mentioned development was made by 'Umar to ensure that armies' welfare was well maintained and that they were able to render their services to the cause of Islam.

Similar to Abū Bakr, 'Umar gave emphasis on moral training of his military personnel. He ordered his military commanders not to start war unless the inhabitants were firstly invited to Islam and that nobody should be forced to accept Islam. "U1 "Umar advised and sent letters to the commanders to follow the way of the Prophet in preaching Islam. ${ }^{92}$ This commandment was manifested in the conquest of Syria and Mesopotamia, the battle of Yarmouk and the fall of Jerusalem. ${ }^{93}$ Besides that, the armies were disallowed to take anything by force from the conquered people. This beautiful method of preaching Islam had attracted many non-Muslims to accept Islam. For instance, after the battle of Qadisiya (14/637), four thousands Persian accepted Islam.

Important developments took place under 'Uthman's chalipate particularly regarding the armed forces. Continuing 'Umar's policy, 'Uthmān increased the number of armed forces and built new cantonments at Tripoli, Cyprus, Armenia and Tabaristan. On the other hand, Islamic history witnessed for the first time a naval force was established in the Islamic state of Medina which later enabled Muslims to gain victory over the Byzantine's empire. ${ }^{94}$ Military expeditions gave a big contribution to the caliphate of 'Uthmān where Muslim territories had expanded from Kabul to Morocco. ${ }^{95}$

Continuous civil wars among Muslims during the caliphate of 'Alī had made the extension of Muslim territories became disabled. Nevertheless, there were some parts conquered by the Muslim armies. For the development of armies, 'Alī built new cantonments and a number of fortresses in Syria as well as army

90 Mohd Yusri Ngah, "Latihan dalam Pembangunan Kerjaya dari Perspektif Pengurusan Islam: Kajian di ILHAM, MARA," 54-67.

91 Majid Ali Khan, The Pious Caliphate, 84.

92 Al-Ṭabarī, Tārīkh al-Rusūl wa al-Mulūk, 126.

93 Ibn al-Athīr, Al-Kāmil fì Tārīkh, 499-501.

94 Hugh Kennedy, The Prophet and the Age of the Caliphates, 71.

95 Al-Suyūṭi, Tārīkh al-Khulafāa, 155; Ibn al-Athīr, al-Kāmil fī Tārīkh, 3:88; AlNajjār, Al-Khulafā' 'al-Rāshidūn, 249. 
posts along the Syrian border. ${ }^{96}$ On the other hand, following his predecessors in their administrations, "Alī was also concerned on moral and self improvement of his employees. Once, he gave specific order to his governor regarding the mentioned above:

"He orders him to fear God and persist in obedience to Him, to follow what he has ordered in His Book: the obligations and recommendations which are the only source of happiness for those who follow them and the cause of misery for those who deny and neglect them. He also orders him to serve God in all sincerity in his heart, deeds and talk, God al-Mighty has promised to support him and to give those who fight for him the upper hand over their enemies. He further orders him to restrain himself from following his passions and to control the excessiveness of his soul since man's soul often leads him astray unless God's mercy keeps him away from evil." $" 97$

As been stated previously, "Alī gave useful advice to his governors upon their appointment, wrote to his governors and sent commissions to check on some officers and dismissed immoral governor. In fact, 'Alī did not only advise his officers but his relatives too of their misbehaviour. 'Ali once ordered his cousin, 'Abdullah Ibn 'Abbas to return the money of ten thousand dirhams he had taken from Bayt al-Māl. Besides that, he paid the price of honey and fat that were taken by his daughter from the land tax (Kharaj). In addition, 'Alī sent monitors to far regions to check and assess governors and officers. ${ }^{98}$ All the above indicates 'Alī's efforts in improving and upgrading the moral and performance of his governors and officers.

Hence, training and development in Islam is a comprehensive practice which includes training and development of behaviour, mind and physical aspects which later lead to quality human capital. Human capital is an important asset to an organization as it is able to provide excellent services to organization. In fact, this practice had been applied in the era of Khulafä' al-Rāshidin and proved to be a successful one as been mentioned previously.

\footnotetext{
6 Al-Najjār, Al-Khulafā' al-Rāshidūn, 213.

97 Syed Omar Syed Agil, Djasriza Jasin and Fatimah Pa'Swan, 'Nine Islamic Management Practices and Habits in Islamic History: Lesson for Managers and Leaders", UNITAR E-Journal 3, no.2 (2007), 47.

98 Abbas J. Ali, "Islamic Challenges to HR in Modern Organizations," 692-71.
} 


\section{Salary and Allowance in the Era of Khulafä' Al-Rāshidīn}

Wage or salary is defined as certain amount of money being paid based on an agreement between an employer and employee for a service that has been done. Wages should be fairly given to employees to ensure their loyalties to employer and to prevent them from taking action for personal interests. This is to ensure that they are able to provide necessities in life such are food, clothing, dwelling, etc. Salary given should not be less to that of a minimum wage in an Islamic society such as RM900. There should not be a big gap between wages among employees as been practised in present capitalist countries. Apart from that, employee needs to be given compensation based on difficulties of job and number of working hours. Moreover, cost of living also needs to be taken into account in granting wages and medical aids should be given to employees sufficiently. ${ }^{99}$

Working and career building are essential in Islam because through working, humans are able to gain salaries that enable them to support their lives and families. Islam discourages idleness ${ }^{100}$ and forbids Muslims from scrounging from others since those who give to others are nobler than those who received. Therefore, Muslims are encouraged to work in accordance to Islamic regulation in which salary, allowance and compensation received are free from things that are forbidden by Islam. The encouragement to work in Islam could be seen from the story of 'Umar al-Khatțāab. Once, 'Umar entered a mosque and realized two Muslims were praying to Allah. He asked them what they were doing whereas other people were busy working. They replied that indeed they were the people who prayed to Allah. 'Umar was very angry upon hearing the answer and replied that both of you were lazy to work although you know that the sky will not rain gold and silver. ${ }^{101}$

In term of salary, the first caliph, Abū Bakr had stipulated several factors on compensation in Islam. One of them is that

99 Afzalur-Rahman, Doktrin Ekonomi Islam, terj. Zaharah Salleh (KL: Dewan Bahasa \& Pustaka, 1991), 231-287.

100 Al-Mutairi, "An Islamic Perspective on Public Service with Reference to the Hajj Research Center (HRC)," 52.

${ }^{101}$ Al-Mutairi, "An Islamic Perspective on Public Service with Reference to the Hajj Research Center (HRC)," 52. 
compensation terms must be clear and known by employee through the presence of witness. Besides, salary should be paid once a job is completed. Deferment of salary needs to be agreed by employee through the presence of witness. Salary given must be appropriate with the difficulty of a work, the condition and the capability of employee. Lastly, pension should be given upon retirement and even after the death of employee. ${ }^{102}$ As a caliph, Abu Bakr received salaries as much as 6,000 dirhams a year from the Bayt al-Māl (Public Treasury) but later ordered his family to repay the money by selling his land. Al-Wāqidī mentions that before his death, Abū Bakar made a will asking 'Umar to return the money (6,000 dirhams) to the Bayt al-Māl ${ }^{103} \mathrm{Al}-$ Suyūtī reports that after the death of Abu Bakr, 'Umar and 'Abd al-Rahmān b. 'Awf checked the Bayt al-Māl and found only one dirham in it. This proves Abū Bakr as a great and noble stateman who was very concerned on the properties belonged to Bayt al-Māl but was very strict on the matter of salary. ${ }^{104}$

In the time of 'Umar, he prepared a reasonable salary scheme and it was relatively high compared to usual need at that time. ${ }^{105}$ It is said that he gave married workers higher salary compared to that of unmarried workers. ${ }^{106}$ 'Umar paid his officers high salaries to prevent them from committing bribery and corruption. For example, $Q \bar{a} d \bar{c} s$ were given 500 dirhams every month and governors 1000 dirhams. ${ }^{107}$ Meanwhile, a soldier received 200-300 dirhams annually as well as personal necessities and allowances given to his family during his involvement in battles. ${ }^{108}$ Some military officers were given salaries from 7,000-10,000 dirhams annually. Besides salaries to officers and soldiers, it is said that 'Umar was the first caliph to give salaries to Imam and muezzin. ${ }^{109}$ He also gave 15 dinar (15 dinar = RM 8972.81) to those who taught al-Quran and one dinar is similar to 4.25 grams of gold.

\footnotetext{
102 Junaidah Hashim, Human Resource Management, 127.

${ }^{103}$ Al-Wāqidī, Kitāb al-Ṭabaqāt al- Kabīr, 137.

104 Al-Suyūțī, Tārīkh al-Khulafā, 79; Majid Ali Khan, The Pious Caliphate, 47.

${ }^{105}$ Syed Omar Syed Agil, Sejarah Kepimpinan dalam Pentadbiran Islam, 245.

${ }^{106}$ Azman Che Omar, Pengurusan di Malaysia dari Perspektif Islam (Kuala Lumpur: Dewan Bahasa \& Pustaka, 68.

${ }^{107}$ Majid Ali Khan, The Pious Caliphate, 94.

${ }^{108}$ Majid Ali Khan, The Pious Caliphate, 108.

${ }^{109}$ Majid Ali Khan, The Pious Caliphate, 97.
} 
'Umar used to arrange wages for civil servants according to hardship, condition of a town (its living standard), nature of a task and their personal needs. ${ }^{110} \mathrm{He}$ frequently went around the city of Madinah and its vicinity to survey the condition of the people. He ensured that slaves and workers were not forced to work beyond their ability physically or mentally. If a disagreement occurred between employer and employee concerning wage, Islam allows the Islamic state to intervene and resolve the conflict justly and equitably. ${ }^{111}$ Meanwhile, aids to the sick were given to employees where 'Umar ensured that taking care and visiting sick slaves and workers became one of the responsibilities of government officials. Apart from basic salary, employees were given pension, unemployment insurance benefit and accident compensation during unemployment season from the zakāh fund. In fact, nonMuslims too were given pensions and stipends from the Bayt al$M \bar{a} l$. In term of compensation, it is said that compensations among senior members of 'Umar's group were given based on their closeness to the Prophet and precedence to Islam. It means that those who had the mentioned criteria will obtain more than other group. ${ }^{112}$ The above description on salaries in the time of 'Umar proves that caliph 'Umar was indeed generous to his employees but as a caliph, he just took two dirham as his salary.

The third caliph, 'Uthmān b. 'Affān is also a man of high character and it is reported that he never take any salary as a caliph from Bayt al-Māl. ${ }^{113}$ In fact, 'Uthmān donated 60,000 dirhams to the Bayt al-Mãl after his 12 years' service. He increased allowances for military personnels due their services in protecting the Islamic state of Madinah. 'Alī b. Abī Țālib succeeded 'Uthmān as the fourth caliph and he gave specific order to his officer on full salary payment to employees, "Full salary payment would create honest and persistent officials and prevent them from taking government's money. If they were still breaking trust after the order being issued, you are entitled to punish them." Besides that, Abbas J. Ali quoted from Kurd Ali saying that in his letter to Al-

${ }^{110}$ Abbas J. Ali, "Islamic Challenges to HR in Modern Organizations," 692-71.

111 Hakim Mohammad Said, Hubungan Majikan Pekerja Menurut Islam, 142157.

112 Abbas J. Ali, "Islamic Challenges to HR in Modern Organizations," 692-71.

113 Majid Ali Khan, The Pious Caliphate, 151. 
Asthar (governor of Egypt), "Alī said to his governor, "Show recognition of their subordinate's good deeds. Repeat your appreciation of the achievements of those who do well. That will encourage the valorous and entice the reluctant." 114

\section{Conclusion}

Human resource management practices that were implemented in the era of Khulafā' al-Rāshidīn is certainly a continuous policy of the Prophet Muhammad (p.b.u.h.). The significance of quality human resource as been stressed by Islam is manifested in the selection and recruitment, training and development of employees as well as salary under Abū Bakar al-Siddīq, 'Umar al-Khatțāb, 'Uthmān b. 'Affān and 'Alī b. Abī Țālib's caliphate. The similarities of the human resource management policies among the four caliphs are that employees were mainly appointed among the Sahābah and selection and appointment of employees were generally conducted after consulting the Shürā. These policies prove to be successful especially during the reign of 'Umar alKhaț̣āb in which Islamic state of Madinah was peaceful and prosperous. Indeed, Islamic empire during Khulafä' al-Rāshidīn had extended to Iraq, Iran, Syria, Palestine, Egypt and from Kabul to Morocco.

Several complaints and cricticisms were made against the administrations of 'Uthmān and 'Alī due to their approaches in carrying out the policies, but in general, Islamic civilization started and developed in the era of al-Rāshidīn. Selection and recruitment, training and development of employees as well as salary during the above mentioned periods succeeded to become examples to the following caliphates i.e. the Umayyad caliphate and continued to be practised by the 'Abbasid caliphate. Therefore, contemporary Islamic World should follow the above human resource management policies of the Khulafä' Al-Räshidin in the effort of to restore the glory of Islamic Civilization to its place.

\section{Bibliography}

Hau, I.S.C. and Ping, P.F. "Change and Development in Pluralistic Settings: An Exploration of Human Resource Practices in Chinese Township and Village Enterprises", International

${ }^{114}$ Abbas J. Ali, "Islamic Challenges to HR in Modern Organizations," 692 - 71. 
Journal of Human Resource Management 11, no.4 (2000): 822836.

Khatri, N. "Managing Human Resource for Competitive Advantage: A Study of Companies in Singapore", International Journal of Human Resource Management 11, no.2 (2000): 336365.

Paul, A.K. and Anantharaman, R.N. "Impact of People Management Practices on Organizational Performance: An Analysis of a Casual Model", International Journal of Human Resource Management 14, no.7 (2003): 1246-1266

Singh, K. "The Effect of Human Resource Practices on Firm Performance in India," Human Resource Development International 6, no. 1 (2003): 101-116.

Al-Hilalī, Muḥammad Taqī al-Dīn and Khān, Muhammad Muḥsīn. Noble Qur'an English Translation of the Meanings and Commentary. Madinah al-Munawwarah: King Fadh Complex For The Printing of the Holy Qur'an, 1997.

Al-Mutairi, Hezam Mater. "An Islamic Perspective on Public Service with Reference to the Hajj Research Center (HRC)." Ph.D Thesis, State University of New York, 1987.

Al-Dhahabī, Muhammad b. Aḥmad b. 'Uthmān. Tārīkh al-Islām wa-Tabaqāt al-Mashāhir wa al-'Alām. Cairo: Maktabah alQudsī, 1927.

Khan, Majid Ali. The Pious Caliphate. Kuala Lumpur: Islamic Book Trusts, 1998.

Kennedy, Hugh. The Prophet and the Age of the Caliphates. London and New York: Longman, 1986.

Husayn Ahmad Amin. Seratus Tokoh dalam Sejarah Islam. Bandung: Penerbit PT Remaja Rosdakarya, 1999.

Hasanuddin Ahmed. A Concise History of Islam: Essays on the Religio-Political History of Islam. New Delhi: Goodwork Books, 2008.

Madelung, Wilferd. The Succession to Muhammad: A Study of the Early Caliphate. New York: Cambridge University Press, 1997. Ibn al-Athīr, 'Izz al-Dīn. Al-Kāmil fì Tārīkh. Beirut: Dār al-Ṣādir, 1979.

Al-Najjār, 'Abd al-Wahāb. Al-Khulafā' al-Rāshidūn. Beirut: Dār al-Kutub al-'Ilmiyyah, 1990. 
Muir, Sir William. The Caliphate Its Rise, Decline, and Fall. London: Darf Publisher, 1984.

Al-Wakīl, Muḥammad al-Sayyid. Jawlah Tārīkhiyah fì 'Așr alKhulafā' al-Rāshidīn. Jeddah: Dār al-Mujtama', 1997.

Al-Șallābī, 'Alī Muḥammad Muḥammad. Al-Khulafā' al-Awwal Abū Bakr al-Siddīq. Beirut: Dār al-Ma'rifah, 2005.

Mokhtar Abdullah, Noreha Hussain, Nik Mustapha Nik Hassan and Mazilan Musa. Essays on Islamic Management and Organizational Performance Measurements. Kuala Lumpur: IKIM, 2003.

Talib Samat. Abu Bakar As-Siddiq Khalifah al-Rasyidin Pertama. Shah Alam: Karisma Publications, 2004.

Al-Ṭabarī, Abī Ja'far Muḥammad b. Jarīr. Tārīkh al-Rusūl wa alMulūk. Mesir: Dār al-Ma'ārif, 1962.

Al-Wāqidī, Muḥammad b. Sa'ad Khāțib. Kitāb al-Ṭabaqāt alKabìr. Leiden: Brill, 1810.

Lapidus, Ira M. A History of Islamic Societies. USA: Cambridge University Press, 1988.

Mustafa Daud. Pengurusan Islam. Selangor: Utusan Publications and Distributors Sdn. Bhd., 1997.

Syed Omar Syed Agil. Sejarah Kepimpinan dalam Pentadbiran Islam dalam Pengurusan dan Pentadbiran. Kuala Lumpur: IKIM, 1998.

Hakim Mohammad Said. Hubungan Majikan Pekerja Menurut Islam, terj. Yusof Ismail. Kuala Lumpur: A.S. Noordeen, 1989.

Abbas J. Ali, "Islamic Challenges to HR in Modern Organizations," Personnel Review 39, no. 6 (2010): 692 - 71.

Junaidah Hashim. Human Resource Management: Islamic Approach. PJ: Prentice Hall, 2007.

Weeramantry, C.G. Islamic Jurisprudence an International Perspective. Kuala Lumpur: The Other Press, 2001.

Ahmad Ibrahim Abu Sin. Pengurusan dalam Islam. Kuala Lumpur: Dewan Bahasa dan Pustaka, 1997.

Naceur Jabnoun. Islam and Management. Kuala Lumpur: Institut Kajian Dasar, 1994.

Naceur Jabnoun. Islam and Management. Kuala Lumpur: Institut Kajian Dasar, 1994.

Abbas J. Ali. "Islamic Challenges to HR in Modern Organizations." Personnel Review 39, no. 6 (2010): 69-71. 
Nor Azzah Kamri. "Nilai dan Etika dalam Pengurusan Islam." Dissertation, Academy of Islamic Studies, University of Malaya, 2002.

Al-Suyūṭī, Jalāl al-Dīn 'Abd al-Raḥmān. Tārīkh al-Khulafā'. Kaherah: Maṭba'at al-Fajālah al-Jadīdah, 1969.

Al-Balādhurī, Ạ̣mad b. Yahyyā. Anșāb al-Ashrāf. Baghdad: Maktabah al-Muthanna, 1936.

Syed Omar Syed Agil, Djasriza Jasin and Fatimah Pa'Swan, "Nine Islamic Management Practices and Habits in Islamic History: Lesson for Managers and Leaders", UNITAR E-Journal 3, no.2 (2007), 47;

Junaidah Hashim. "Islamic Revival in Human Resource Management Practices Among Selected Islamic Organisations in Malaysia", International Journal of Islamic and Middle Eastern Finance and Management 2, no. 3 (2009): 251-267.

Mohd Yusri Ngah. "Latihan dalam Pembangunan Kerjaya dari Perspektif Pengurusan Islam: Kajian di ILHAM, MARA." Dissertation, Academy of Islamic Studies, University of Malaya, 2004.

Afzalur-Rahman. Doktrin Ekonomi Islam, terj. Zaharah Salleh.

Kuala Lumpur: Dewan Bahasa dan Pustaka, 1991. Azman Che Omar. Pengurusan di Malaysia dari Perspektif Islam. Kuala Lumpur: Dewan Bahasa dan Pustaka, t.t.).

"Umar", website Wikipedia, retrieved on 20 July 2010, http://en.wikipedia.org/wiki/Umar. 